\title{
Evaluation of Abscisic Acid Analogs as Holding Agents for Bedding Plant Seedlings
}

\section{Nirmala Sharma ${ }^{1}$, Suzanne R. Abrams ${ }^{2}$, and Doug R. Waterer ${ }^{1,3}$}

ADDITIONAL INDEX WORDS. tomato, snapdragon, nasturtium, moisture use, root dip, racemic ABA

SumMARY. The marketing period of nursery-raised bedding plant seedlings is limited by the loss of aesthetic quality associated with undesirable growth and/or excess moisture loss during storage and handling. Long-lasting synthetic analogs of abscisic acid (ABA) $\left(8^{\prime}\right.$-methylene ABA methyl ester and $8^{\prime}$-acetylene ABA methyl ester) were evaluated for their potential use in controlling growth and extending the marketing period of seedlings of tomato (Lycopersicon esculentum), snapdragon (Antirrbinum majus), and nasturtium (Tropelaum majus). $\mathrm{ABA}$ analogs, applied as root-dips, slowed moisture use and reduced seedling growth in a dosage-dependent manner with no significant phytotoxic effects over the short term. The nature and duration of the responses of the three test crops to the ABA analog treatments were similar. ABA analogs were more effective at reducing moisture use by tomato seedlings than regular $\mathrm{ABA}$ and also had fewer negative effects on plant appearance. Before $\mathrm{ABA}$ analogs can be recommended for commercial-scale use, their impact on long-term performance needs to be determined, along with an evaluation of their cost and safety relative to other plant growth retardants.

$\mathrm{T}$ he marketing period of bedding plants and vegetable transplants is limited due to the loss of aesthetic quality associated with undesirable growth and/or excess moisture loss during storage and handling. Plant growth regulators like paclobutrazol, uniconazole, and ancymidol are presently applied to container-grown ornamental and nursery plants to control growth, limit stem elongation, and slow moisture use, thereby producing more compact, easily maintained plants (Gibson and Whipker, 2000; McDonald and Arnold, 2001; Whipker and McCall, 2000; Whipker et al., 2000). Plant growth retardants also increase the stress tolerance of plants during shipping and handling and retail marketing, thereby improving shelflife and extending plant marketability (Latimer, 2001). However, these products tend to have long-term negative effects on plant growth and development (Gibson and Whipker, 2003; McDonald and Arnold, 2001) and are not registered for use in vegetable crops (Cantliffe, 1993; Latimer, 1991). The effects of these plant growth regulators also vary

${ }^{1}$ Department of Plant Sciences, University of Saskatchewan, Saskatoon, SK, Canada S7N 5A8.

${ }^{2}$ National Research Council/Plant Biotechnology Institute, Saskatoon, SK, Canada S7N 0W9.

${ }^{3}$ To whom reprint requests should be addressed: e-mail address: waterer@sask.usask.ca among species and cultivars (White et al., 2005), making it difficult to develop appropriate application strategies.

The hormone ABA regulates plant growth and stress physiology (Addicott, 1983). ABA reduces water loss from the leaves by regulating the aperture of the stomata (Walton, 1980). ABA-induced retardation of stomatal gaseous exchange also reduces photosynthesis and thereby slows plant growth (Arteca and Tsai, 1987; Kramer, 1988; Loveys, 1991; Salisbury and Ross, 1992). Foliar-applied ABA significantly decreased stomatal conductance, transpiration rate, and net photosynthesis in greenhousegrown potato (Solanum tuberosum) (Baricevic and Stopar, 1994). Similarly, foliar-applied ABA decreased transpiration and slowed wilting of pot-grown tomato and cucumber (Cucumis satious) seedlings and also reduced plant growth (Yamazaki et al., 1995). Root-applied ABA also slowed shoot and root growth of tomato, cucumber, and sunflower (Helianthus annums) seedlings (Griffiths et al., 1997; Lenzi et al., 1995). Foliar application of ABA at $10^{-4} \mathrm{M}(2641 \mathrm{ppm}), 4$ weeks after seeding, reduced leaf growth, root dry weight, and basal root count of pepper (Capsicum annuum) seedlings (Leskovar and Cantliffe, 1992). The ABA treatments did not influence long-term growth and yield potential of the transplants. Leskovar and Cantliffe (1992) suggested that exogenous application of ABA might represent a substitute for drought stress as a means to control transplant growth in the nursery.

At present, the use of the natural hormone $\mathrm{ABA}$ is limited due to its instability in solution and its rapid deactivation by photoisomerization and metabolism (Abrams, 1999; Flores and Dorflling, 1990). To address this problem, synthetic analogs of ABA have been developed that mimic the effects of ABA but are more stable, longer lasting, and relatively simple to synthesize (Abrams, 1999).ABA-like compounds have been developed that are highly effective as anti-transpirants (Dorffling, 1985; Jung and Grossmann, 1985; Schubert et al., 1991). Todoroki et al . (1995) reported that fluorinated ABA analogs $\left(8^{\prime}, 8^{\prime}\right.$-difluroabscisic acid and $8^{\prime}, 8^{\prime}, 8^{\prime}$-trifluroabscisic acid) inhibited growth of rice (Oryza sativa) seedlings more effectively than $\mathrm{ABA}$. $\mathrm{ABA}$ analogs $8^{\prime}$-methylene and $8^{\prime}$-acetylene were superior to $\mathrm{ABA}$ in inhibiting growth of suspension-cultured corn (Zea mays) cells and reducing transpiration in wheat (Triticum aestivum) seedlings (Abrams et al., 1997; Cutler et al., 2000).

In a preliminary greenhouse study in which $8^{\prime}$-methylene and $8^{\prime}$ acetylene $\mathrm{ABA}$ analogs were applied as root-dip treatments to bedding plants of marigold (Calendula officinalis), petunia (Petunia $\times$ bybrida), tomato, and pumpkin (Cucurbita pepo), these $\mathrm{ABA}$ analog treatments reduced plant moisture use and shoot growth (D.R. Waterer, unpublished). Concentration,

\begin{tabular}{llll}
\hline $\begin{array}{l}\text { Units } \\
\text { To convert U.S. to SI, } \\
\text { multiply by }\end{array}$ & U.S. unit & SI unit & $\begin{array}{l}\text { To convert SI to U.S., } \\
\text { multiply by }\end{array}$ \\
\hline 29.5735 & $\mathrm{fl} \mathrm{oz}$ & $\mathrm{mL}$ & 0.0338 \\
2.5400 & inch $(\mathrm{es})$ & $\mathrm{cm}$ & 0.3937 \\
16.3871 & inch & $\mathrm{cm}^{3}$ & 0.0610 \\
28.3495 & $\mathrm{oz}$ & $\mathrm{g}$ & 0.0353 \\
1 & $\mathrm{ppm}$ & $\mathrm{mg} \cdot \mathrm{L}^{-1}$ & 1 \\
$\left({ }^{\circ} \mathrm{F}-32\right) \div 1.8$ & ${ }^{\circ} \mathrm{F}$ & ${ }^{\circ} \mathrm{C}$ & $\left(1.8 \times{ }^{\circ} \mathrm{C}\right)+32$
\end{tabular}

Hortlechnology • January-March 2006 16(1) 
analog, and crop-specific effects were observed. These studies suggested that $\mathrm{ABA}$ analogs might have potential for application as holding agents for ornamentals and nursery plants, provided effective crop-specific and situation-appropriate treatments are identified.

This study was designed to evaluate the potential to use ABA analogs to slow moisture use and control growth of bedding plants and to compare their efficacy with regular ABA.

\section{Materials and methods}

Plant materials, treatments, AND EXPERIMENTAL DESIGN. Trials were conducted in the greenhouses of the Department of Plant Sciences, University of Saskatchewan, using seedlings of 'Manitoba' tomato, 'Rose Red' snapdragon, and 'Rose' nasturtium. Seedlings of all crops were grown in $85-\mathrm{cm}^{3}$ cell packs containing Sunshine Mix 4 (Sun Gro Horticulture, Missisauga, Ont., Canada). Greenhouse conditions during production of the seedlings and the subsequent trial periods were $23 / 18{ }^{\circ} \mathrm{C}$, day/night temperature with a 14 -h day length. Supplemental light was provided with halogen lamps $\left(200 \mu \mathrm{mol} \cdot \mathrm{m}^{-2} \cdot \mathrm{s}^{-1}\right)$. Seedlings were fertilized with 200 ppm of $20 \mathrm{~N}-8.8 \mathrm{P}-16.6 \mathrm{~K}$ fertilizer solution every third day throughout the evaluation period.

In the first experiment, which was conducted with tomato seedlings, $8^{\prime}$-methylene ABA methyl ester (PBI 365 ) and 8'-acetylene ABA methyl ester (PBI 429) (Fig. 1) were evaluated at concentrations of $10^{-5} \mathrm{M}, 5 \times$ $10^{-5} \mathrm{M}$, and $10^{-4} \mathrm{M}$. For PBI 365 these molar concentrations correspond to solutions containing 290, 1450, and 2990 ppm of PBI 365, respectively. For PBI 429 the corresponding solutions were 288, 1440, and 2881 ppm, respectively. Both $\mathrm{ABA}$ analogs were synthesized and provided by the Plant Biotechnology Institute of National Research Council of Canada (Saskatoon, Sask.). Based on the results from the first trial, snapdragon and nasturtium were treated with either 5 $\times 10^{-5} \mathrm{M}$ or $10^{-4} \mathrm{M}$ of each ABA analog. A third experiment compared racemic $\mathrm{ABA}$ with the ABA analogs at $5 \times$ $10^{-5} \mathrm{M}(1320 \mathrm{ppm})$ and $10^{-4} \mathrm{M}(2641$ $\mathrm{ppm})$. A higher concentration $\left[10^{-3}\right.$ $\mathrm{M}(26,414 \mathrm{ppm})]$ of regular $\mathrm{ABA}$ was also included in this trial. In all trials, the ABA or its analogs were dissolved in $1 \%$ acetone solution and applied to 4-week-old seedlings as a root-dip by immersing the cell packs containing the plants in the appropriate solution until they reached holding capacity (about 10 s). A 1\% aqueous acetone solution served as the control treatment. On average, $40 \mathrm{~mL}$ of the $\mathrm{ABA}$ analog solution was needed for treatment of each seedling. Following application of the ABA treatments, the cell packs were arranged in a randomized completeblock design on a greenhouse bench, with four replicates per treatment.

Depending upon crop type, the trials were terminated 9 to $12 \mathrm{~d}$ after treatment application, at which time there was no longer any difference between control and treated plants in terms of daily moisture use. This suggested that the ABA analog treatment effects had dissipated. Alternatively, the trials were terminated when the control plants had grown to the point where their daily moisture needs exceeded the moisture-holding capacity of the cell packs.

Data COllected. The amount of water used daily by the seedlings was determined by weighing the cell packs before watering and then subtracting that weight from the weight of the cell packs after rewatering to holding capacity. Plant heights were measured at the beginning and end of the evaluation period. Shoot fresh weights were measured at the termination of the trial. The effects of the ABA analog treatments on general plant appearance (leaf color and shape) and plant development were noted, including number of leaves per plant, and time of appearance of floral buds and flowers.

Statistical analysis. All plant growth parameters were subject to analysis of variance using an appropriate randomized complete-block

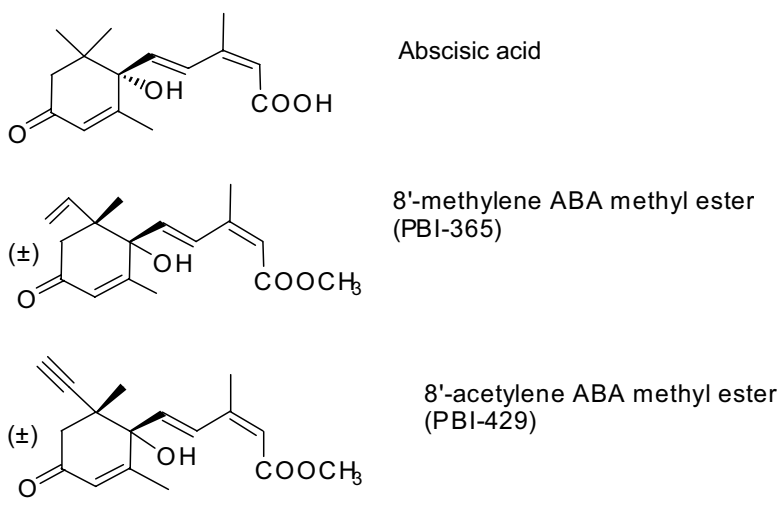

Fig. 1. Structures of abscisic acid (ABA) and two ABA analogs. design (RCBD) model utilizing the GLM program of SAS (SAS Institute, 1987). All F-tests were carried out at $P \leq 0.05$. Data on daily moisture use were analyzed as a simple RCBD model, using the data from each day as a separate variable. Least significant difference tests $(P=0.05)$ were used for comparison of treatment means. Preplanned single degree-of-freedom contrasts were used to evaluate specific treatment responses.

\section{Results}

No significant changes in appearance were observed as a result of application of the ABA analogs except when PBI 429 was applied at the highest concentration $\left(10^{-4} \mathrm{M}\right)$. In both tomato and nasturtium, this treatment caused slight yellowing of leaves beginning 1 week after treatment and continuing for the duration of the trial. The analog treatments had no effect on leaf number for nasturtium or snapdragon (data not shown). Floral bud counts for all three test crops were not influenced by the ABA treatments (data not shown)

Tomato. The effects of ABA analog treatments on daily water use, averaged over the three concentrations tested for each analog are presented in Fig. 2. The ABA analog treatments significantly reduced plant moisture use relative to the control beginning $2 \mathrm{~d}$ after treatment and continuing through the $10-\mathrm{d}$ evaluation period (Fig. 2). Plant moisture use by the ABA analog-treated plants was relatively high at the beginning of the evaluation period, then declined for the next $4 \mathrm{~d}$, and again increased toward the end of the evaluation period (Fig. 2). The total amount of moisture used per plant over the evaluation period was reduced by $9 \%$ to $62 \%$, depending on 
the $\mathrm{ABA}$ analog treatments (Table $\mathrm{l}$ ). Total water use declined with increasing $\mathrm{ABA}$ analog concentration (Table 1) and PBI 429-treated plants used significantly less moisture than plants treated with PBI 365 (Table 1).

Leaf number per plant was significantly smaller in the $\mathrm{ABA}$ analog treatments (Table 1), with the PBI 429 treatments having a greater effect on leaf number than PBI 365. The number of leaves per plant also declined with increasing concentrations of ABA analogs (Table 1). Shoot elongation, measured as the change in height from the beginning to the end of the evaluation period, was reduced by $24 \%$ to $67 \%$ by the $\mathrm{ABA}$ analog treatments relative to the control (Table 1). Overall, PBI 429 slowed shoot elongation more than PBI 365 (Table 1). Shoot elongation decreased in response to increasing concentrations of the $\mathrm{ABA}$ analogs, with $5 \times 10^{-5}$ $M$ and $10^{-5} \mathrm{M}$ concentrations showing more effect for PBI 429 than for PBI 365 (Table 1). Shoot fresh weight at the final harvest was $31 \%$ higher in the control plants than the average of the ABA analog treatments (Table 1). Shoot fresh weight decreased with increasing concentrations of the ABA analogs applied (Table 1) and plants treated with PBI 365 produced higher mean shoot fresh weights than those treated with PBI 429 (Table 1).

SnAPDRAgON. The ABA analog treatments significantly reduced plant moisture use by the snapdragon, beginning $\mathrm{l} \mathrm{d}$ after application and continuing through to the end of the 12-d evaluation period (Fig. 3). The $10^{-4} \mathrm{M}$ solution of both analogs caused a greater reduction in moisture use than the $5 \times 10^{-5} \mathrm{M}$ treatment (Fig. 3 and Table 2). Beginning at $6 \mathrm{~d}$ after treatment and continuing through the remainder of the trial, daily moisture use of snapdragon seedlings treated with PBI 365 was significantly higher than those receiving PBI 429 at similar concentrations. Total moisture use by the $\mathrm{ABA}$ analog treatments over the $12-\mathrm{d}$ evaluation period was reduced by an average of $41 \%$ relative to the control (Table 2).

Cumulative shoot elongation over the evaluation period was, on average, $54.2 \%$ lower for the ABA analog treatments than for the controls (Table 2). PBI 429 caused a greater reduction in shoot elongation $(65.7 \%)$ compared to PBI $365(43 \%)$. The $5 \times 10^{-5} \mathrm{M}$

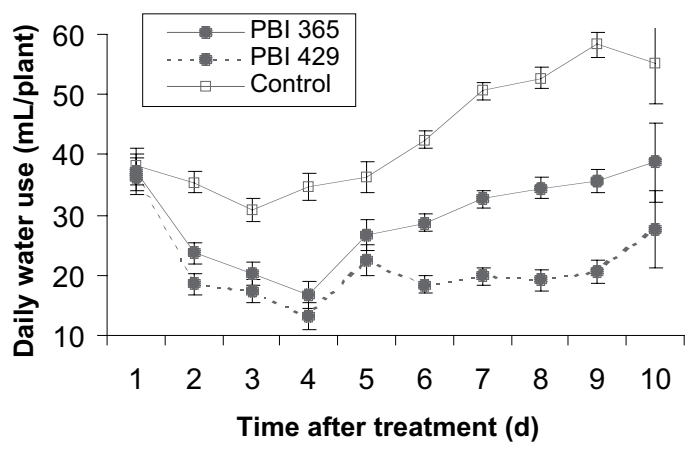

Fig. 2. Daily water use by abscisic acid (ABA) analog-treated tomato seedlings over a 10-d evaluation period. Vertical bars represent $\pm \mathrm{SE}$. Values for the ABA analogs are the average of $10^{-4} \mathrm{M}, 5 \times 10^{-5} \mathrm{M}$, and $10^{-5} \mathrm{M}$ treatments. PBI 365 $=8^{\prime}$ - methylene abscisic acid methyl ester (molecular weight $=290.15 \mathrm{~g}$ ). PBI $429=8^{\prime}$-acetylene abscisic acid methyl ester $($ molecular weight $=288.14 \mathrm{~g})$. For PBI 365, the $10^{-4} \mathrm{M}, 5 \times 10^{-5} \mathrm{M}$, and $10^{-5} \mathrm{M}$ treatments correspond to solutions containing 2900, 1450, and 299 ppm of PBI 365, respectively. For PBI 429, the $10^{-4} \mathrm{M}, 5 \times 10^{-5} \mathrm{M}$, and $10^{-5} \mathrm{M}$ treatments correspond to solutions containing 2880,1440 , and $288 \mathrm{ppm}$ of PBI 429 , respectively $(1 \mathrm{~g}=0.0353 \mathrm{oz} ; 1 \mathrm{ppm}=1$ $\left.\mathrm{mg} \cdot \mathrm{L}^{-1} ; 1 \mathrm{~mL}=0.0338 \mathrm{fl} \mathrm{oz}\right)$.

Table 1. Single degree-of-freedom contrasts and treatment means for moisture use and growth characteristics during a 10 -d evaluation period of tomato plants treated with abscisic acid (ABA) analogs (PBI 365 or PBI 429) as a root dip.

\begin{tabular}{|c|c|c|c|c|}
\hline Sources & $\begin{array}{c}\text { Total } \\
\text { water use } \\
(\mathrm{mL} / \text { plant })^{\mathrm{z}}\end{array}$ & $\begin{array}{c}\text { Shoot } \\
\text { elongation } \\
(\mathrm{cm})^{\mathrm{y}}\end{array}$ & $\begin{array}{c}\text { Shoot } \\
\text { fresh wt } \\
(\mathrm{g} / \text { plant })^{x}\end{array}$ & $\begin{array}{c}\text { Leaves } \\
\text { (no./plant) }\end{array}$ \\
\hline \multicolumn{5}{|c|}{ Contrasts } \\
\hline Analogs vs. control & $* * *$ & $\star * *$ & *** & $* * *$ \\
\hline Analog type & $* * *$ & ** & $* * *$ & $* * *$ \\
\hline Analog concn (L) & $* * *$ & * & $* * *$ & $* * *$ \\
\hline Analog concn (Q) & * & $* * *$ & $* * *$ & NS \\
\hline Analog $\times \operatorname{concn}(\mathrm{L})$ & * & * & NS & NS \\
\hline Analog $\times \operatorname{concn}(\mathrm{Q})$ & NS & NS & * & NS \\
\hline \multicolumn{5}{|c|}{ Treatment means } \\
\hline \multicolumn{5}{|l|}{ PBI 429w } \\
\hline $10^{-5} \mathrm{M}$ & 395.1 & 3.5 & 17.7 & 6.1 \\
\hline $5 \times 10^{-5} \mathrm{M}$ & 269.0 & 2.3 & 13.9 & 5.7 \\
\hline $10^{-4} \mathrm{M}$ & 213.6 & 1.4 & 9.4 & 5.1 \\
\hline Average & 292.6 & 2.4 & 13.6 & 5.6 \\
\hline \multicolumn{5}{|l|}{ PBI $365^{\mathrm{v}}$} \\
\hline $10^{-5} \mathrm{M}$ & 265.3 & 2.5 & 13.4 & 7.3 \\
\hline $5 \times 10^{-5} \mathrm{M}$ & 191.7 & 1.1 & 9.0 & 6.6 \\
\hline $10^{-4} \mathrm{M}$ & 163.4 & 1.4 & 8.0 & 5.9 \\
\hline Average & 206.8 & 1.6 & 10.1 & 6.6 \\
\hline Control & 434.6 & 3.3 & 17.3 & 7.4 \\
\hline $\operatorname{LSD}(P \leq 0.05)$ & 38.8 & 0.9 & 2.2 & 0.7 \\
\hline
\end{tabular}

${ }^{\mathrm{z}} 1 \mathrm{~mL}=0.0338 \mathrm{fl} \mathrm{oz}$

$\mathrm{y} 1 \mathrm{~cm}=0.3937$ inch.

${ }^{\mathrm{x}} \mathrm{lg}=0.0353 \mathrm{oz}$.

'PBI $429=8^{\prime}$-acetylene abscisic acid methyl ester (molecular weight $=288.14 \mathrm{~g}$ ). The $10^{-4} \mathrm{M}, 5 \times 10^{-5} \mathrm{M}$, and $10^{-5}$ $\mathrm{M}$ treatments correspond to solutions containing 2881,1440 , and $288 \mathrm{ppm}\left(\mathrm{mg} \cdot \mathrm{L}^{-1}\right)$ of PBI 429 , respectively. ${ }^{v}$ PBI $365=8^{\prime}$-methylene abscisic acid methyl ester (molecular weight $=290.15 \mathrm{~g}$ ). The $10^{-4} \mathrm{M}, 5 \times 10^{-5} \mathrm{M}$, and $10^{-5} \mathrm{M}$ treatments correspond to solutions containing 2900,1450 , and $299 \mathrm{ppm}$ of PBI 365 , respectively. NS, ${ }^{*},{ }^{* *},{ }^{* *}$ Nonsignificant or significant at $P=0.05,0.01$, or 0.001 , respectively.

concentration of both analogs allowed more shoot elongation than the $10^{-4}$ M treatment (Table 2). Shoot fresh weights at the final harvest were also significantly greater in the control plants compared to the ABA analog treatments (Table 2). Plants treated with PBI 365 produced heavier shoots than those treated with PBI 429 at identical concentrations (Table 2) 
and shoot fresh weight decreased with increasing concentrations of the $\mathrm{ABA}$ analogs.

Nasturtium. Daily moisture use by the nasturtium seedlings declined relative to the controls starting $\mathrm{l} \mathrm{d}$ after application of the ABA analog treatments and this effect continued through the 9-d evaluation period (Fig. 4). Total moisture use per plant over the evaluation period for the ABA analog-treated plants was $25 \%$ lower than the control (Table 3). PBI 429 was more effective in reducing plant moisture use compared to PBI 365. The $10^{-4} \mathrm{M}$ treatment was more effective at reducing plant moisture use than the $5 \times 10^{-5} \mathrm{M}$ treatment (Fig. 4).

Cumulative shoot elongation of $\mathrm{ABA}$ analog-treated nasturtium plants was, on average, $29.5 \%$ lower than for the control (Table 3). PBI 429 caused less shoot elongation (35\% of control) than PBI 365 (24\%) and this effect was greater in $10^{-4} \mathrm{M} \mathrm{ABA}$ analog treatments than those treated with $5 \times 10^{-5} \mathrm{M}$ (Table 3 ). Shoot fresh weights at the final harvest were, on average, $10 \%$ higher in the control plants compared to those receiving the ABA analog treatments (Table 3 ). PBI 429 produced lower mean shoot fresh weights than PBI 365 at identical concentrations (Table 3). Shoot fresh weights also declined with increasing concentrations of the ABA analogs.

ABA ANALOGS vS. RACEMIC ABA. The highest concentration $\left(10^{-3} \mathrm{M}\right)$ of regular ABA appeared phytotoxic, as the tomato seedlings wilted despite the presence of adequate available moisture. This response was observed within $1 \mathrm{~d}$ of treatment application and lasted for $3 \mathrm{~d}$ (data not shown).

Both regular ABA and the analogs began to significantly reduce daily water use by the tomato plants within 1 d of treatment (Fig. 5). However, the effects of regular ABA were weaker than corresponding concentrations of the ABA analogs (Fig. 5 and Table 4). The regular ABA treatments suppressed moisture use only for $3 \mathrm{~d}$ while the analogs continued to suppress moisture use through to the end of the evaluation period (Fig. 5). On average, the ABA analog treatments reduced moisture use by $30 \%$ relative to the control and by $25 \%$ relative to racemic $\mathrm{ABA}$ (Table 4). Treatment with PBI 429 caused a greater reduction in plant moisture use than PBI 365 (Fig. 5 and Table 4). Differences between the relative

Table 2. Single degree-of-freedom contrasts and treatment means for moisture use and growth characteristics during a 12-d evaluation period of snapdragon plants treated with abscisic acid (ABA) analogs (PBI 365 or PBI 429) as a root-dip.

\begin{tabular}{lccc}
\hline Sources & $\begin{array}{c}\text { Total } \\
\text { water use } \\
(\mathrm{mL} / \text { plant })^{\mathrm{z}}\end{array}$ & $\begin{array}{c}\text { Shoot } \\
\text { elongation } \\
(\mathrm{cm})^{\mathrm{y}}\end{array}$ & $\begin{array}{c}\text { Shoot } \\
\text { fresh wt } \\
(\mathrm{g} / \mathrm{plant})^{\mathrm{x}}\end{array}$ \\
\hline Analogs vs. control & $* * *$ & Contrasts & $* *$ \\
Analog type & $* *$ & $* *$ & $* * *$ \\
Analog concn $(\mathrm{L})$ & $* *$ & $*$ & $\mathrm{NS}$ \\
Type $\times$ concn $(\mathrm{L})$ & $\mathrm{NS}$ & $*$ & $*$ \\
& \multicolumn{2}{c}{ Treatment means }
\end{tabular}

PBI $429^{\mathrm{w}}$

$\begin{array}{llll}5 \times 10^{-5} \mathrm{M} & 89.1 & 2.5 & 6.6\end{array}$

$10^{-4} \mathrm{M} \quad 64.6 \quad 2.5 \quad 5.6$

$\begin{array}{lll}\text { Average } & 76.8 & 2.5\end{array}$

PBI $365^{\mathrm{v}}$

$5 \times 10^{-5} \mathrm{M} \quad 105.6 \quad 4.8 \quad 7.1$

$\begin{array}{llll}10^{-4} \mathrm{M} & 85.6 & 3.5 & 6.2\end{array}$

$\begin{array}{lll}\text { Average } & 95.6 & 4.2\end{array}$

$\begin{array}{llll}\text { Control } & 145.6 & 7.3 & 8.8\end{array}$

LSD $(P \leq 0.05) \quad 14.5 \quad 0.9 \quad 1.2$

${ }^{2} 1 \mathrm{~mL}=0.0338 \mathrm{fl} \mathrm{oz}$

${ }^{y} 1 \mathrm{~cm}=0.3937$ inch.

${ }^{\mathrm{x}} 1 \mathrm{~g}=0.0353 \mathrm{oz}$.

"PBI $429=8^{\prime}$-acetylene abscisic acid methyl ester $\left(\right.$ molecular weight $=288.14 \mathrm{~g}$ ). The $10^{-4} \mathrm{M}$ and $5 \times 10^{-5} \mathrm{M}$ treatments correspond to solutions containing 2881 or $1440 \mathrm{ppm}\left(\mathrm{mg} \cdot \mathrm{L}^{-1}\right)$ of PBI 429 , respectively.

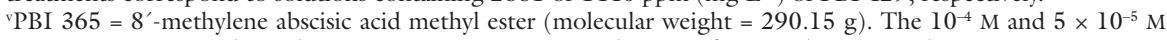
treatments correspond to solutions containing 2900 or $1450 \mathrm{ppm}$ of PBI 365, respectively.

NS, ${ }^{* * *},{ }^{* * *}$ Nonsignificant or significant at $P=0.05,0.01$, or 0.001 , respectively.

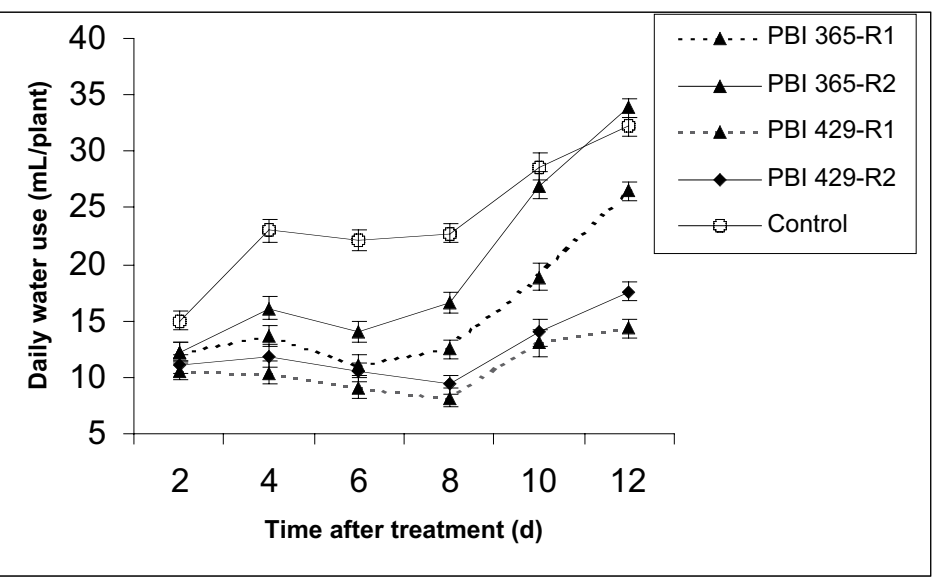

Fig. 3. Daily water use by abscisic acid (ABA) analog-treated snapdragon seedlings over a 12-d evaluation period. Vertical bars represent \pm SE. $R 1=10^{-4} \mathrm{M}, \mathrm{R} 2=5 \times 10^{-5}$ M. PBI $365=8^{\prime}$-methylene abscisic acid methyl ester (molecular weight $=290.15$ g). PBI $429=8^{\prime}$-acetylene abscisic acid methyl ester ( molecular weight $=288.14$ g). For PBI 365, the $10^{-4} \mathrm{M}$ and $5 \times 10^{-5} \mathrm{M}$ treatments correspond to solutions containing 2990 or $1450 \mathrm{ppm}$ of PBI 365, respectively. For PBI 429, the $10^{-4} \mathrm{M}$ and $5 \times 10^{-5} \mathrm{M}$ treatments correspond to solutions containing 2881 or $1440 \mathrm{ppm}$ of PBI 429, respectively $\left(1 \mathrm{~g}=0.0353 \mathrm{oz} ; 1 \mathrm{ppm}=1 \mathrm{mg} \cdot \mathrm{L}^{-1} ; 1 \mathrm{~mL}=0.0338 \mathrm{fl} \mathrm{oz}\right)$.

efficacies of the two analogs were apparent $2 \mathrm{~d}$ after treatment application and persisted for the duration of the evaluation period.

Shoot elongation over the evaluation period, was reduced by $62.5 \%$ in the PBI 429 treatments and by $27 \%$ in the PBI 365 treatments relative to the controls (Table 4). No significant difference was observed between the heights of plants treated with regular $\mathrm{ABA}$ and the control plants. Total shoot fresh weights at the termination of the trial for plants treated with the ABA analogs were significantly lower than for plants treated with either racemic ABA or the untreated controls (Table 4). No significant effect of analog type 


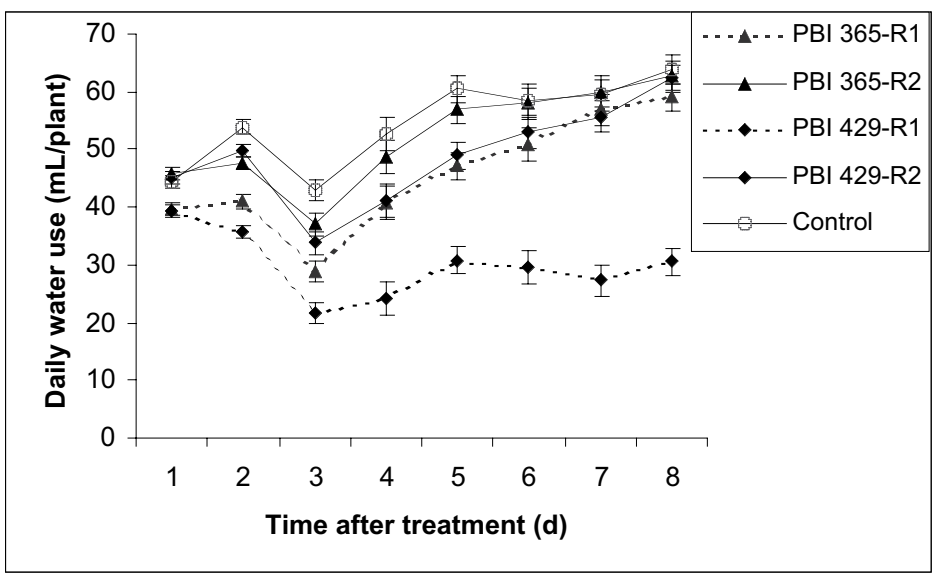

Fig. 4. Daily water use by abscisic acid (ABA) analog-treated nasturtium seedlings over a 9-d evaluation period. Vertical bars represent $\pm \mathrm{SE}$. $\mathrm{Rl}=10^{-4} \mathrm{M}, \mathrm{R} 2=5 \times 10^{-5}$ M. PBI $365=8^{\prime}$-methylene abscisic acid methyl ester (molecular weight $=290.15$ g). PBI $429=8^{\prime}$-acetylene abscisic acid methyl ester $($ molecular weight $=288.14$ g). For PBI 365, the $10^{-4} \mathrm{M}$ and $5 \times 10^{-5} \mathrm{M}$ treatments correspond to solutions containing 2990 or 1450 ppm of PBI 365, respectively. For PBI 429, the $10^{-4} \mathrm{M}$ and $5 \times 10^{-5} \mathrm{M}$ treatments correspond to solutions containing 2881 or $1440 \mathrm{ppm}$ of

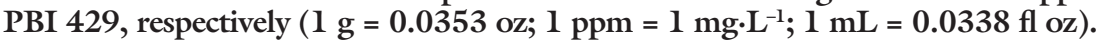

Table 3. Single degree-of-freedom contrasts and treatment means for growth characteristics during a 9-d evaluation period of nasturtium plants treated with abscisic acid (ABA) analogs (PBI 365 or PBI 429) as a root-dip.

\begin{tabular}{|c|c|c|c|}
\hline Sources & $\begin{array}{c}\text { Total } \\
\text { water use } \\
(\mathrm{mL} / \text { plant })^{\mathrm{z}}\end{array}$ & $\begin{array}{c}\text { Shoot } \\
\text { elongation } \\
(\mathrm{cm})^{\mathrm{y}}\end{array}$ & $\begin{array}{c}\text { Shoot } \\
\text { fresh wt } \\
(\mathrm{g} / \text { plant })^{\mathrm{x}}\end{array}$ \\
\hline \multicolumn{4}{|c|}{ Contrasts } \\
\hline Analogs vs. control & $* * *$ & * & *** \\
\hline Analog type & $* * *$ & NS & $* * *$ \\
\hline Analog concn (L) & $* * *$ & * & $* * *$ \\
\hline Type $\times$ concn $(\mathrm{L})$ & ** & NS & NS \\
\hline \multicolumn{4}{|c|}{ Treatment means } \\
\hline \multicolumn{4}{|l|}{ PBI 429w } \\
\hline $5 \times 10^{-5} \mathrm{M}$ & 336.7 & 2.1 & 14.9 \\
\hline $10^{-4} \mathrm{M}$ & 199.7 & 1.4 & 11.2 \\
\hline Average & 268.2 & 1.8 & 13.0 \\
\hline \multicolumn{4}{|l|}{ PBI $365^{\mathrm{v}}$} \\
\hline $5 \times 10^{-5} \mathrm{M}$ & 358.8 & 2.3 & 16.0 \\
\hline $10^{-4} \mathrm{M}$ & 310.7 & 1.8 & 13.4 \\
\hline Average & 334.8 & 2.0 & 14.7 \\
\hline Control & 403.7 & 2.7 & 15.3 \\
\hline $\operatorname{LSD}(P \leq 0.05)$ & 31.6 & 0.7 & 1.2 \\
\hline
\end{tabular}

${ }^{2} 1 \mathrm{~mL}=0.0338 \mathrm{fl} \mathrm{oz}$.

y $1 \mathrm{~cm}=0.3937$ inch.

${ }^{\mathrm{x}} 1 \mathrm{~g}=0.0353 \mathrm{oz}$.

'PBI $429=8^{\prime}$-acetylene abscisic acid methyl ester (molecular weight $=288.14 \mathrm{~g}$ ). The $10^{-4} \mathrm{~m}$ and $5 \times 10^{-5} \mathrm{~m}$ treatments correspond to solutions containing 2881 or $1440 \mathrm{ppm}\left(\mathrm{mg} \cdot \mathrm{L}^{-1}\right)$ of PBI 429 , respectively.

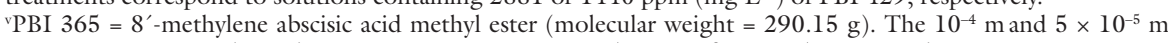
treatments correspond to solutions containing 2900 or $1450 \mathrm{ppm}$ of PBI 365, respectively.

NS, ${ }^{*},{ }^{* *},{ }^{* * *}$ Nonsignificant or significant at $P=0.05,0.01$, or 0.001 , respectively.

was observed on shoot fresh weights. Treatment with regular ABA resulted in no significant change in shoot fresh weights relative to the controls (Table 4).

\section{Discussion}

Chemical holding agents are used by the nursery industry to minimize plant maintenance costs, to extend the marketing period and to reduce the risk of dehydration stress during storage and shipping. Ideally, a holding agent checks plant growth at a desired growth stage for a predictable and manageable period of time, with no detrimental effects on plant appearance or long-term negative effects on plant performance.
The plant growth regulators used as chemical holding agents tend to impart species- and cultivar-specific effects (White et al., 2005) necessitating trials to develop appropriate application strategies. In this study, ABA analog treatments significantly reduced total moisture use; slowed shoot elongation and controlled growth of tomato, snapdragon, and nasturtium seedlings with minimal negative effects on plant appearance or development. An analog and dosage-dependent reduction in leaf number per plant was observed in ABA analog-treated tomato seedlings but not in snapdragon or nasturtium. Floral bud counts, however, were not significantly altered in any of the test crops. According to White et al. (2005), plant growth regulators may suppress plant height with or without bloom delay.

The ABA analog-induced reduction in plant moisture use is likely the result of the ABA analogs reducing stomatal conductance (Grossnickel et al., 1996; Sharma, 2002; Walton, 1980). Total moisture use over the evaluation period for all three crops was positively correlated with shoot fresh weights at the termination of the trials (data not shown). This correlation suggests that increased stomatal resistance may be an immediate effect of the ABA analogs on plant moisture use, but over the longer term the associated reduction in plant size may also contribute to the reduction in moisture use. Growth and development processes affected by $\mathrm{ABA}$, such as cell division, cell expansion and growth, and ultimately reduction in leaf size, stomatal index, and stomata size can all influence plant water use (Davies and Jones, 1991; Quarrie, 1991). ABA is known to counteract the growth-promoting effects of auxins and gibberellins (Davies, 1995). Many of the commercially available plant growth regulators also show anti-gibberellin activity (Davies, 1995; Hartmann et al., 1981; Rademacher, 2000; Schnelle et al., 1993). Reduction in moisture use also occurred when geraniums (Pelargonium $\times$ hortorum) were root-drenched with anti-gibberellin compounds, paclobutrazol, or uniconazole.

PBI 429 was more effective and persistent than PBI 365 for all crops and test parameters evaluated. This likely relates to the fact that PBI 429 is less liable to oxidative breakdown 


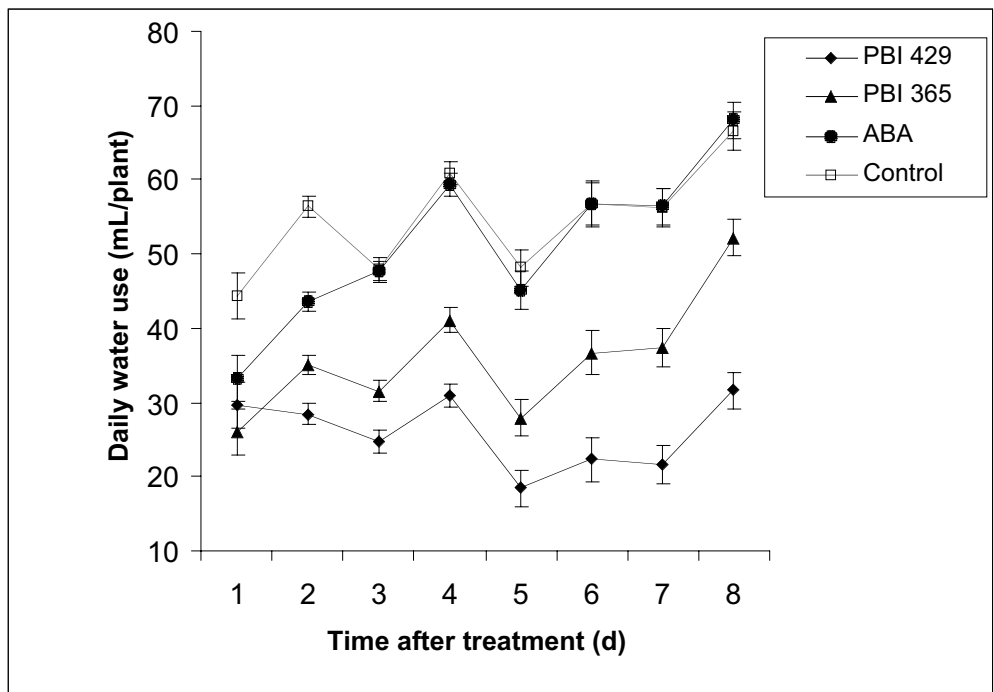

Table 4. Single degree-of-freedom contrasts and treatment means for moisture use and growth characteristics over a 9-d evaluation period of tomato plants receiving varying concentrations of abscisic acid (ABA) or its analogs (PBI 365 or PBI 429) as a root-dip.

\begin{tabular}{|c|c|c|c|}
\hline Sources & $\begin{array}{c}\text { Total } \\
\text { water use } \\
(\mathrm{mL} / \text { plant })^{\mathrm{z}}\end{array}$ & $\begin{array}{c}\text { Shoot } \\
\text { elongation } \\
(\mathrm{cm})^{\mathrm{y}}\end{array}$ & $\begin{array}{c}\text { Shoot } \\
\text { fresh wt } \\
(\mathrm{g} / \text { plant })^{x}\end{array}$ \\
\hline \multicolumn{4}{|c|}{ Contrasts } \\
\hline Analogs vs. control & $* * *$ & $* *$ & $* * *$ \\
\hline Analogs vs. ABA & $* * *$ & $* * *$ & $* * *$ \\
\hline ABA vs. control & NS & NS & NS \\
\hline Analog type & $* * *$ & * & NS \\
\hline \multicolumn{4}{|c|}{ Treatment means } \\
\hline \multicolumn{4}{|l|}{ PBI 429w } \\
\hline $5 \times 10^{-5} \mathrm{M}$ & 346.9 & 1.0 & 23.7 \\
\hline $10^{-4} \mathrm{M}$ & 228.7 & 0.8 & 19.5 \\
\hline Average & 287.8 & 0.9 & 21.6 \\
\hline \multicolumn{4}{|l|}{ PBI $365^{\mathrm{v}}$} \\
\hline $5 \times 10^{-5} \mathrm{M}$ & 230.7 & 1.9 & 24.4 \\
\hline $10^{-4} \mathrm{M}$ & 184.6 & 1.6 & 22.1 \\
\hline Average & 207.6 & 1.7 & 23.2 \\
\hline \multicolumn{4}{|l|}{$\mathrm{ABA}^{\mathrm{u}}$} \\
\hline $5 \times 10^{-5} \mathrm{M}$ & 429.2 & 2.3 & 28.6 \\
\hline $10^{-4} \mathrm{M}$ & 385.7 & 3.2 & 24.5 \\
\hline $10^{-3} \mathrm{M}$ & 270.7 & 2 & 23.2 \\
\hline +Average & 407.4 & 2.7 & 26.4 \\
\hline Control & 434.1 & 2.4 & 29.0 \\
\hline $\operatorname{LSD}(P \leq 0.05)$ & 34.8 & 1.0 & 3.6 \\
\hline
\end{tabular}

${ }^{2} 1 \mathrm{~mL}=0.0338 \mathrm{fl} \mathrm{oz}$

y $\mathrm{cm}=0.3937$ inch.

${ }^{\mathrm{x}} \mathrm{g}=0.0353 \mathrm{oz}$.

"PBI $429=8^{\prime}$-acetylene abscisic acid methyl ester (molecular weight $=288.14 \mathrm{~g}$ ). The $10^{-4} \mathrm{M}$ and $5 \times 10^{-5} \mathrm{M}$ treatments correspond to solutions containing 2881 or $1440 \mathrm{ppm}\left(\mathrm{mg} \cdot \mathrm{L}^{-1}\right)$ of PBI 429 , respectively

${ }^{\text {} P B I} 365=8^{\prime}$-methylene abscisic acid methyl ester (molecular weight $=290.15 \mathrm{~g}$ ). The $10^{-4} \mathrm{M}$ and $5 \times 10^{-5} \mathrm{M}$ treatments correspond to solutions containing 2900 or 1450 ppm of PBI 365 , respectively.

${ }^{\mathrm{u}} \mathrm{ABA}=$ abscisic acid $($ molecular weight $=264.14 \mathrm{~g})$. The $10^{-3}, 10^{-4} \mathrm{M}$, and $5 \times 10^{-5} \mathrm{M}$ treatments correspond to solutions containing $26,414,2641$, or $1320 \mathrm{ppm}$ of ABA, respectively.

Ns, ${ }^{*}, * *, * *$ Nonsignificant or significant at $P=0.05,0.01$, or 0.001 , respectively; $+=$ Average of $5 \times 10^{-5} \mathrm{M}$ and $10^{-4} \mathrm{M}$ treatments.

than PBI 365 (Sue Abrams, personal communication). The extent and duration of the analog effects were concentration dependent. In all three species tested, treatment at $5 \times 10^{-5} \mathrm{M}$ appeared preferable, as it substantially reduced plant moisture requirements, but for a short period, and caused only moderate retardation of plant growth with no visible phytotoxic effects. The effects of PBI 365 at $10^{-4} \mathrm{M}$ were also acceptable, as this treatment did not result in severe retardation of plant growth as observed with PBI 429 at the same concentration. The final choice of the most appropriate concentration and analog type would depend upon the treatment objectives.

A key characteristic of holding agents is that they must check water use and growth only for a limited period of time, with the expectation of rapid and full recovery once the stresses associated with handling, transportation, and transplanting have passed. The severe retardation of plant growth caused by PBI 429 at $10^{-4} \mathrm{M}$ would likely have long-term negative effects on development. In field trials with tomato and pumpkin, treating seedlings with PBI 429 at $10^{-4} \mathrm{M}$ prior to transplanting provided excellent protection against transplanting stress but slowed subsequent plant development, resulting in fewer ripe fruits compared to PBI 365 (Sharma et al., 2006). McDonald and Arnold (2001) found that application of the plant growth retardant uniconazole to blue plumbago (Plumago auriculata) had long-term negative impact on subsequent growth and flowering of the crop.

ABA analogs were both more effective and persistent at reducing moisture use by tomato seedlings than comparable rates of regular $\mathrm{ABA}$. Total moisture use by ABA analog-treated tomato seedlings was comparable to that produced by applying racemic $\mathrm{ABA}$ at 10 to 15 times the concentration of the ABA analogs (Table 4). Abrams et al. (1997) reported greater efficacy of PBI 365 than regular ABA in preventing transpiration in wheat seedlings. Regular ABA is both less effectively absorbed and is also more susceptible to oxidative breakdown 
in the plant system than the analogs (Cutler et al., 2002).

This study showed that rootdip treatments with ABA analogs reduced slowed growth and moisture use by seedlings of three commonly transplanted horticultural crops with minimal negative effects on appearance of the crops. While PBI 429 appeared more effective and persistent than PBI 365 , at high concentrations this analog also caused some phytotoxicity and severely retarded plant growth. The $\mathrm{ABA}$ analogs were more effective and persistent as a holding treatment than corresponding treatments with regular (racemic) ABA.

By applying an appropriate $\mathrm{ABA}$ analog at a suitable concentration, the marketing period of bedding plants may be extended at minimal cost without loss of visual quality associated with undesirable growth and moisture stress during handling and marketing. If the $\mathrm{ABA}$ analogs continue to control moisture loss following transplanting, this may also aid in the establishment of the transplants in the field. Smaller, slower-growing plants are less susceptible to physical damage at transplanting and require less moisture after transplanting, thereby avoiding transplanting stress (Grossnickle et al., 1996; Latimer, 1991). ABA analog-induced stomatal closure would also help avoid dehydration of the seedling following transplanting. Before ABA analogs can be recommended for commercial scale use, the cost effectiveness and safety of $\mathrm{ABA}$ analogs must be compared to other plant growth retardants.

\section{Literature cited}

Abrams, S.R. 1999. Abscisic acid mimics: Chemicals that protect plants from stress. Nwsl., Natl. Res. Council, Plant Biotechnol. Inst., Saskatoon, Sask., Canada.

Abrams, S.R., P.A. Rose, A.J. Culter, J.J. Balsevich, and M.K. Walker-Simmons. 1997. 8'-Methylene ABA: An effective and persistent analog of abscisic acid. Plant Physiol. 144:89-87.

Addicott, F.T. 1983. Abscisic acid. Praeger, New York.

Arteca, R.N. and D.S. Tsai. 1987. Effects of abscisic acid on the photosynthesis, transpiration and growth of tomato plants. Crop Res. 27:91-96.

Baricevic, D. and M. Stopar. 1994. Influence of exogenous abscisic acid (ABA) in potato cultivars 'Saskia' and 'Desiree': Photosynthetic activity in vivo. Zbornik-BiotehniskeFakultete-Univerze-v-Ljubljani-Kmetijstvo 63:57-62.
Cantliffe, D.J. 1993. Pre- and postharvest practices for improved vegetable transplant quality. HortTechnology 3:415-418.

Cutler, A.J., P.A. Rose, T.M. Squires, M.K. Loewen, A.C. Shaw, J.W. Quail, J.E. Krochko, and S.R. Abrams. 2000. Inhibitors of abscisic acid $8^{\prime}$-hydroxylase. Biochemistry 39:13614-13624.

Davies, W.J. and H.G. Jones. 1991. Abscisic acid physiology and biochemistry. Bios Sci. Publ., Oxford, U.K.

Dorffling, K. 1985. VI. Growth. Prog. Bot. 47:142-154.

Flores, A. and K. Dorffling. 1990. A comparative study of the effects of abscisic acid and new terpenoid abscisic acid analogs on plant physiological processes. J. Plant Growth Regulat. 9:133-139.

Gibson, J.L. and B.E. Whipker. 2000. Ornamental cabbage and kale growth response to plant growth regulators. HortScience 35:434. (Abstr.)

Gibson, J.L. and B.E. Whipker. 2003. Efficacy of plant growth regulators on the growth of vigorous Osteospermum cultivar. HortTechnology 13:132-135.

Griffiths, A., H.G. Jones, and A.D. Tomos. 1997. Applied abscisic acid, root growth and turgor pressure responses of roots of wilt type and the ABA-deficient mutant, Notabiis, of tomato. J. Plant Physiol. 151:60-62.

Grossnickle, S.C., R.S. Folk, S.R. Abrams, D.I. Dunstan, and P.A. Rose. 1996. Performance of interior spruce seedlings treated with abscisic acid analogs. Can. J. For. Res. 26:2061-2070.

Hartmann, H.T., W.J. Flocker, and A.M. Kofranek. 1981. Plant science. Growth, development and utilization of cultivated plants. Prentice-Hall, Engelwood Cliffs, N.J.

Jung, J. and K. Grossmann. 1985. Effectiveness of new terpenoid derivatives, abscisic acid and its methyl ester on transpiration and leaf senescence of barley. J. Plant Physiol. 121:361-367.

Kramer, P.J. 1988. Water relations of plants. Academic Press, New York.

Latimer, J.G. 1991. Mechanical conditioning for control of growth and quality of vegetable transplants. HortScience 26:1456-1461.

Latimer, J.G. 2001. Selecting and using plant growth regulators for floricultural crops. Virginia Tech. Publ. No. 430-102.

Lenzi, A., M. Fambrini, S. Barroti, C. Pugliesi, and P. Vernieri. 1995. Seed germination and seedling growth in wilty mutant of sunflower (Helianthus annums L.): Effect of abscisic acid and osmotic potential. Environ. Expt. Bot. 35:427-434.

Leskovar, D.I. and D.J. Cantliffe. 1992. Pepper seedling growth response to drought stress and exogenous abscisic acid. J. Amer. Soc. Hort. Sci. 117:389-393.

Loveys, B.R. 1991. How useful is knowledge of ABA physiology for crop improvement?
245-260. In: W.J. Davies and H.G. Jones (eds. .) Abscisic acid: Physiology and biochemistry. Bios Sci. Publ., Oxford, U.K.

McDonald, G.V. and M.A. Arnold. 2001. Paclobutrazol and uniconazole applications affect production quality and subsequent landscape performance of blue plumbago. HortScience 36:431. (Abstr.)

Quarrie, S.A. 1991. The role of abscisic acid in regulating water status in plants. BioloskiVestnik 39:67-76

Rademacher, W. 2000. Growth retardants: Effects on gibberellin biosynthesis and other metabolic pathways. Annu. Rev. Plant Physiol. Plant Mol. Biol. 51:5021-5031.

Salisbury, F.B. and C.W. Ross. 1992. Plant physiology. 4th ed. Wadsworth, Belmont, Calif.

SAS Institute Inc. 1987. SAS/STAT guide for personal computers. 6th ed. SAS Inst., Cary, N.C.

Schnelle, M.A., B.D. McCraw, and J.M. Dole. 1993. Height control of flowering crops and vegetable transplants. Oklahoma Coop. Ext. Serv., OSU Ext. Facts F-6714.

Schubert, J., K. Roser, K. Grossmann, H. Sauter, and J. Jung. 1991. Transpiration-inhibiting abscisic acid analogs. J. Plant Growth Regulat. 10:27-32.

Sharma, N. 2002. Use of abscisic acid (ABA) analogs to improve performance of horticultural crops. M.Sc. Thesis, Univ. of Saskatchewan, Saskatoon.

Sharma, N., S.R. Abrams, and D. Waterer. 2006. ABA analogs reduce transplanting stress in horticultural plants. J. Veg. Sci. (In press.)

Todoroki, Y., N. Hirai, and K. Koshimizu. 1995. 8', $8^{\prime}$-Difluoro- and $8^{\prime}, 8^{\prime} 8^{\prime}$-trifluoroabscisic acid as highly potent, long-lasting analogs of abscisic acid. Phytochemistry 38:561-568.

Walton, D.C. 1980. Biochemistry and physiology of abscisic acid. Annu. Rev. Plant Physiol. 31:453-489.

Whipker, B.E., S.K. Dasoju, and M.R. Evans. 2000. Vegetatively propagated geraniums respond similarly to drench applications of paclobutrazol or uniconazole. Hort Technology 10:151-153.

Whipker, B.E. and I. McCall. 2000. Response of potted sunflower cultivars to daminozide foliar sprays and paclobutrazol drenches. HortTechnology 10:209-211.

White, S.A., H.L. Scoggins, M.A. Marini, and J.G. Latimer. 2005. Multivariate repeated measures analysis of plant growth regulators on Tradescantia virginiana. HortScience 40:404-408.

Yamazaki, H., T. Nishijima, and M. Koshioka. 1995. Effects of $(+)-S$-abscisic acid on the quality of stored cucumber and tomato. HortScience 30:80-82 